\title{
DAMPAK DAN TANTANGAN DA'WAH DI ERA-GLOBAL
}

\author{
AHMAD MISBAHUL ANAM \\ abmadmisbabulanam@gmail.com \\ Sekolah Tinggi Ilmu Da'wah Mohammad Natsir, Indonesia
}

\begin{abstract}
ABSTRAK
Tujuan Penelitian: Mengungkap dampak Agama Sistemik dalam Masyarakat Global Metode Penelitian: Kualitatif. Hasil Penelitian: Kelahiran Islam dengan ajaran yang sistemik menjadi jawaban penyingkap kabut kejahiliyahan terutama dalam menemukan konsep ketuhanan. Dan Islam dalam konteks sekarang akan melahirkan kekuatan yang akan menjadi lawan tanding bagi globalisasi
\end{abstract}

\section{Kata Kunci: Agama, Sistemik, Global}

\section{PENDAHULUAN}

\section{Pengertian Dakwah}

Dakwah Secara bahasa berarti seruan, panggilan, permintaan, permohonan, dan doa. ${ }^{1}$ Kesemua arti da 'wah ini menurut Achmad Mubarok menunjukkan adanya komunikasi antara dua pihak dan upaya mempengaruhi pihak lain ${ }^{2}$. Maka apabila da 'wah didekati dengan makna harfiyah semata, dakwah itu bisa berorientasi positif dan bisa juga berorientasi negatif. Agar dakwah memiliki kejelasan nilai dan landasan berpijaknya, maka disertakan nama Islam dibelakangnya, jadilah nama "Dakwah Islamiyah”. Menurut Jum ah Amin: “Apabila dikatakan dakwah Islamiyah, maka yang dimaksudkan adalah "Risalah terakhir yang diturunkan kepada Nabi Muhammad saw sebagai wahyu dari Allah. ${ }^{3}$ Maka, antara dakwah sebagai suatu upaya / proses, dengan wahyu sebagai tolok ukur dan materi kebenarannya, dan Islam sebagai institusi agama yang mengusungnya, terdapat hubungan yang sangat erat dan tak

\footnotetext{
${ }^{1}$ A.W. Munawwir, Kamus Al-Munawwir, Edisi kedua, hal 407

2. Achmad Mubarok, Psikologi Dakwah, ( Jakarta: Pustaka Firdaus 2002) Cet. Ke-3 hal 19

${ }^{3}$ Jum ah Amin Abdul Aziz, Fiqih Dakwah, ( Solo: Era Intermedia 2003 )

Cet. Ke-4 hal. 24
} 
mungkin dapat dipisahkan. Dan jika dilihat dari segi penyampai dakwah (da i), dakwah pada zaman yang tantangan dan problema kehidupan semakin kompleks seperti sekarang ini, seorang da'i tidak boleh puas dengan pengulangan-pengulangan materi yang disampaikan dalam dakwahnya saja, tetapi dia juga harus berbekal dengan iman yang kokoh, ilmu yang luas, keterampilan teknis yang memadai dan yang palin penting adalah akhlak mulia sebagai jati dirinya.

Dengan demikian dapatlah disimpulkan bahwa dakwah adalah suatu upaya (proses) mewujudkan tatanan kehidupan yang islami. Dengan kata lain dakwah adalah suatu upaya memfungsikan Al-Qur'an dalam kehidupan secara optimal. Maka dakwah juga mengandung makna Islamisasi, Qur`anisasi. Karena itu, tak satu sudutpun dari kehidupan manusia muslim lepas dari kontrol Qur`an, dan tak satu bidangpun dari kehidupan manusia muslim luput dari celupan Allah (shibghatullab). Sehingga Islam (melalui proses dakwah) menjadi pedoman hidup seorang muslim secara total.

\section{Pengertian Globalisasi}

Istilah Globalisasi sering diberi arti yang berbeda antara satu dengan yang lainnya. Akbar S. Ahmed dan Hastings Donnan memberi batasan bahwa globalisasi pada prinsipnya mengacu pada perkembanganperkembangan yang cepat dalam teknologi komunikasi, transformasi, informasi yang bisa membawa bagian -bagian dunia yang jauh menjadi hal-hal yang bisa dijangkau dengan mudah. ${ }^{4}$ Sedangkan menurut Bambang Pranowo5, kata "Global" menunjuk kepada kondisi dari kehidupan umat manusia yang semakin ditandai dengan sifat-sifat yang cenderung serupa di seluruh sudut dunia. Sedangkan kata "Globalisasi" menunjuk kepada proses di mana umat manusia di seluruh dunia semakin digabungkan satu sama lain sehingga mengarah kepada terbentuknya suatu masyarakat tunggal yaitu "Masyarakat Global".

Ahli ekonomi dan sosiologi terkenal, Jalal Amin mengatakan, "Istilab Globalisasi adalab istilah baru, namun fenomenanya cukup lama. Maka kita memahami globalisasi adalah adalah penyempitan jarak secara cepat antara masyarakat manusia, baik yang berkaitan dengan perpindahan barang, orang,

${ }^{4}$ Akbar S. Ahmad dan Hastings Donnan, Islam; Globalization and Posmodernity, (London : Routledge, 1994), l. Mereka mendasarkan referensi dari A. Giddens, The Conseauences of Modernity, (Canbridge: Polity Press, 1990), h. 64

${ }^{5}$ M. Bambang Pranowo, Tantangan Global Pribadi Muslim, (Pokok-pokok pikiran disampaikan pada acara Tazkiyah Afidah, diselenggarakan oleh Yayasan Rumah Sakit Islam Jakarta, 24 Mei 2003), h. 1 
modal, informasi, pemikiran maupun nilai-nilai, sehingga tampak globalisasi bagi kita adalab sepertinya mengiringi perkembangan peradaban manusia". ${ }^{6}$

Menurut Yusuf Al-Qardhawi, globalisasi terjemahan dari kata (bahasa) Perancis: Monodialisation yang artinya menjadikan sesuatu mendunia atau bersifat internasional, yakni menjadikannya dari terbatas dan terawasi kepada tidak terbatas dan sulit diawasi. Yang dimaksud dengan "terbatas" ialah levelnya hanya level nasional yang dibatasi oleh batas-batas geografis dan dibawah pengawasan badan pengawas khusus misalnya terhadap keluar masuknya barang dan di bawah perlindungan badan khusus baik yang berkaitan dengan ekonomi, politik atau kebudayaan, sedang yang dimaksud tidak terbatas adalah dunia. ${ }^{7}$

Melihat fenomena diatas kita bisa menduga, globalisasi adalah sebuah istilah, dalam masyarakat ekonomi berarti pasar. Cara pandang terhadap globalisasi bisa bermacam-macam, boleh jadi ia dilihat sebagai kejadian, sebagai sebuah fenomena, sebagai ajaran, sebuah isme atau sebuah filsafat. Sebagi sebuah pemikiran yang mendunia harus diwaspadai karena ia adalah kelanjutan dari cara berfikir kolonialisme dan imperialisme jaman dulu tapi dipoles lebih canggih. Berikutnya sebagaimana tema pembicaraan kita, tentu hubungan agama dan globalisasi dalam kontek pegertian diatas pasti akan terjadi interaksi dua arah. Agama dipengaruhi globalisasi dan pada saat yang sama agama akan mempengaruhi globalisasi. Oleh sebab itu bagi aktifis 'pegiat da'wah' era global adalah lahan yang harus dihadapi dan kancah untuk mengolahnya menjadi actor atau paling tidak menjadi co-aktor. Bukan hanya menjadi obyek dan jatuh menjadi victim-nya, korban dari globalisasi ${ }^{8}$. Kemunculannya di awal tahun 90-an yang pada awalnya adalah era komunikasi yang ditandai dengan munculnya internet, ternyata pengaruhnya bukan hanya pada dunia informasi tapi pelan dan pasti merambah hampir di keseluruhan kehidupan. Dalam tulisan makalahnya M. Bambang Pranowo menyebutkan bahwa,

6 Jalal Amin dalam Muqaddimah Kitab Al-Ailamah wa At-Tanmiyyah AlArabiyyah min Hamlati Nabuliyon Ila Jaulah Urughuway, (Beirut: Markaz Dirasat AlWihdah al-Arabiyah, t.t.)

${ }^{7}$ Yusuf Al-Qardhawy, Islam dan Globalisasi Dunia, (Jakarta: Pustaka AlKautsar, 2001). h. 22

8 Ziaudin Sardar, Islam Tanpa Syariat: Menggali universalitas tradisi, Grafindo, hal.169-170. Dalam kolom tanya jawab Prof. Nur Ahmad Fadhli lubis membuat klausul, bahwa jalan keluar untuk tidak menjadi obyek globalisasi, l.para da'I harus harus melaksanakan refleksi ulang terhadap ajaran agama yang dirumuskan pada masa lalu supaya tetap relevan pada masa sekarang, dan 2. Para da'I harus memahami perubahan-perubahan yang ada dalam masyarakat sehingga dia bisa memahami dan menjawab persoalan (jangan eklusif) harus ada ijtihad baru. 
"Dalam proses globalisasi keberadaan berbagai komunitas manusia dapat dianalogikan dengan sekumparan benang yang dijalin menjadi selembar kain yang berwarna-warni. Sekali benang tersebut terjalin menjadi selembar kain maka tak mungkin lagi dapat dipisabkan dari kain tersebut. Helai benang bany a bermakna dalam posisinya sebagai bagian dari kain secara keseluruban. Proses globalisasi yang berujung pada terbentuknya msyarakat global tersebut ditandai dengan terjadinya berbagai kecenderungan sebagai berikut: 1. Perubahan konsep mengenai ruang dan waktu, 2. Volume interaksi cultural yang semakin meningkat, 3. Kesamaan problem penduduk dunia, 4. Saling bubungan dan saling-ketergantungan yang semakin berkembang, 5. Menguatnya jaringan actor dan organisasi transnasional, dan 6. Sinkronisasi dari segenap dimensi globalisasi".

Dalam era post kapitalisme, globalisasi telah menjadi sebuah kendaraan untuk membawa paham kapitalis ke negara-negara non kapitalis melalui liberalisme institusi-institusi. Pertumbuhan teknologi informasi menjadi kekuatan baru dan akan segera merubah keadaan dunia menjadi "akbir sebuah sejarah" (the end of history) dan dimulainya babak baru era demokrasi liberal. Bagi setiap manusia keberadaan globalisasi menjadi 'alam kasunyatan' yang tidak bisa ditolak karena ia hadir sebagai fasilitas ke arah 'kemajuan' yang radikal. Malcom Walters menyebutkan,

“... bangkitnya paham kapitalisme menghadirkan dinamisasi global. Kapitalisme merupakan bentuk produksi yang efektif yang telah memberikan keistimewaan berupa kekuatan untuk menganutnya. Kekuatan ini dapat digunakan untuk mengurangi atau babkan mengbapus otoritas agama-agama, politik, militer dan sumber kekuatan lainya". ${ }^{10}$

Penyebutan masyarakat global mengindikasikan adanya ciri masyarakat yang hidup di era informasi terkini yang satu sama lainnya dihubungkan dengan berbagai jenis sistem perangkat komunikasi mutakhir. "Kita terjepit di antara gugusan-gugusan tradisionalisme yang hampir terlupakan dan modernisme yang menindas masyarakat muslim", tulis Zardar ${ }^{11}$. Di tengah situasi dunia yang seakan mengecil inilah hubungan dan informasi antar manusia semakin tanpa jarak dan waktu, intensitas ini kalau kita lacak akan saling mempengaruhi berbagai bidang seperti ekonomi, sosial, budaya, politik, ideologi, agama, literatur bahkan

${ }^{9}$ Pranowo, M.Bambang, Prof, Dr, Dalam Tantantangan Global Pribadi Muslim, Pokok pikiran disampaikan pada acara Tazkiyah Afidah Yayasan RSIJ di Pusdiklat Pegawai ASKES, Cisarua 24 mei 2003

${ }^{10}$ Roubaie, Amer.Prof.Dr, Jurnal Islamia, th. 1 no.4 2005, hal.10-11

${ }^{11}$ Op.cit, Zardar, hal. 286-287 
mode dari belahan bumi yang satu dengan lainya. Amer Rubaie menukil apa yang di sebutkan oleh John Tomlinson, meng-intisarikan arti globalisasi dengan:

"Proses hubungan yang rumit antar masyarakat luas dunia, antar budaya, institusi dan individual. Globalisasi merupakan proses sosial yang mempersingkat waktu dan jarak dari pengurangan waktu yang diambil baik secara langsung maupun tidak langsung. Jadi dengan dipersingkatnya jarak dan waktu, dunia dilibat seakan-akan semakin mengecil dalam beberapa aspek, yang membuat bubungan manusia antar satu dengan yang lain semakin dekat"12.

Kerumitan membuat pengertian globalisasi, rupanya juga berdampak terhadap kehidupan sosial masyarakat. Dampak dari pengaruh globalisasi yang paling berbahaya adalah ekses terhadap budaya. Akibatnya, karena negara-negara berkembang umumnya tidak dalam posisi siap untuk menghentikan arus informasi-informasi tersebut ke dalam masyarakat mereka. Hal ini dikarenakan terbatasnya teknologi komunikasi dan sarana media penyiaran.

\section{HASIL DAN DISKUSI}

\section{Budaya dan Imperialisme Global}

The new Encyclopedia Britanica menyebutkan,

"Budaya adalab model dari ilmu pengetahuan manusia, kepercayan dan pola tingkah laku yang berlaku. Budaya kemudian dilibat mempunyai aspek dari segi bahasa, ide, keyakinan, adat istiadat, kode moral, institusi, teknologi, seni ritual, upacara-upacara dan komponen-komponen lainnya yang saling berkaitan. Perkembangan budaya tergantung kepada kapasitas manusia untuk terus mempelajari budaya itu dan mentransmisikan ilmu pengetabuan mereka kepada generasi berikutnya". ${ }^{13}$

Budaya global yang beredar saat ini dikuasai dan disebarkan melalui interaksi budaya Barat ke beberapa negara yang lain. Budaya barat memiliki produk yang bercirikan, materialsitik yang akan menyebabkan pergolakan dan konflik sosial di masyarakat non Barat, yang mempunyai warisan budaya dan kehidupan religius yang berbeda-beda. Ciri kebudayan barat yang memang anti agama menguatkan keberadaannya sebagai bagian yang nantinya akan banyak mempengaruhi ide-ide besar

\footnotetext{
${ }^{12}$ Ibid, Roubaie, hal 11

${ }^{13}$ The new Encyclopedia Britanica, vol.3 hal 784
} 
globalisasi dunia. Dan kesan dunia terhadap penyebutan barat setelah era keruntuhan Soviet yang pada awalnya adalah rival kebijakan dunia mengakibatkan jatuhnya benturan peradapan. Jatuhnya Soviet, munculnya era informasi yang berbasis kabel optic dan dunia maya serta tragedy 11 September, seakan ingin menegaskan apa yang sudah lama diprediksi oleh para pemikir barat tentang jatuhnya pilihan bahwa pesaing peradaban yanga akan dihadapi bersama-sama adalah kekuatan Islam.

Kesamaan merek konsumsi antara satu kawasan dengan kawasan yang lain melompat bergantian, bahkan melahirkan kelompok fanatic di pusat kota terutama di negara-negara berkembang, tanda-tanda kultur kaum muda internasional terdapat hampir dimana-mana. "Dunia semakin kosmopolitan dan saling mempengaruhi satu sama lain," ujar dasainer Paloma Picasso ${ }^{14}$. Sampai tahun 2000-an tercatat 2 miliar penumpang pesawat hilir mudik melakukan perpindahan dari satu tempat ke tempat lain. Citra gaya hidup menjalar ke seluruh penjuru dunia dengan kecepatan cahaya, menyebarkan isinya kemana-mana ${ }^{15}$.

"Imperialisme cultural", tulis kolumnis Georgie Geyer, “merembes ke suatu negara melalui radio dan TV, melalui turis dan perawat tentara perdamaian, imperialisme cultural melangkah memasuki negara kuno yang menderita seperti Iran yang diperalat oleh orang yang dianggap berniat baik dari Kota Sioux, yang sebenarnya adalah setan, dengan membawa bersama mereka Big macs, hak-hak wanita, nilai relativisme dan toleransi. Hiburan melalui medium bahasa dan citra melintas melewati garis pertukaran superficial dan memasuki ranah nilai. Hiburan langsung masuk ke etos kultur, mengarahkan semangat fundamental yang menginformasikan kepercayaan dan prakteknya. Bahasa adalah penghubung terbesar ke jantung suatu kultur ${ }^{16}$. Bahasa adalah agen homogenisasi, frekuensi kultur ditransformasikan .

Lambat laun walaupun kultur lahir dari masing-masing budaya lokal, namun karena adanya IT, bahasa dan peralatan komunikasi, keberadaan kultur lokal tersebut akan menguat dan dicicipi oleh warga di belahan lain. Semakin umat manusia memandang dirinya sebagai penghuni planet ini, semakin besar kebutuhan bagi setiap kultur untuk diwarisi. Namun, bila proses luar itu mulai mengoreksi lingkungan nilainilai yang lebih dalam, orang akan kembali menekankan perbedaan mereka, semacam serangan balasan kultural. Sejarah, bahasa dan tradisi setiap negara adalah unik. Maka, dengan cara yang paradoks, semakin kita

${ }^{14}$ John Naisbitt \& Patricia Abutrdene, Megatrens 2000 Sepuluh Arah Baru untuk tahun 1990-an, Bina Aksara Jakarta, Cet. I 1990, hal. 106

${ }^{15}$ Ibid, Naisbitt, hal. 109

${ }^{16}$ Ibid, hal. 125-126 
bersentuhan terhadap kesamaan budaya global, semakin terlihat masingmasing akan menekankan keunikan masing-masing dan akhirnya tidak menutup kemungkinan lahirnya penolakan dengan cara 'revolusioner'.

Lahirnya demokrasi akibat dari pengaruh globalisasi telah memberikan dampak kemajuan fisik-material manusia sesuai dengan budaya yang dibangunya. Apabila demokrasi membawa kepada kemajuan dan kesejahteraan manusia, maka siapapun akan menerimanya. Akan tetapi, benarkah demokrasi akan membawa semua itu bagi manusia? Atau ada konsekwensi-konsekwensi lain, disamping positifnya, yang mengikat dalam mengikuti demokrasi? Pertanyaan terakhir penting sekali untuk direnungkan, mengingat fakta sejarah yang telah ditunjukkan Negara yang mengklaim demokrasi adalah pemicu otoritarian, biang terorisme dan kampium dictator dengan baju global democratization (demokrasi dunia) ${ }^{17}$.

Demokrasi seperti 'setan gundul' karena selalu disalah artikan dengan hanya sekedar bentuknya yang di-impor (baca: dipaksakan) dari produk budaya yang lain. Padahal inti yang ada dalam demokrasi kalu dikembalikan ke bahasa aslinya, demos yang berarti rakyat dan cratos yang berarti kekuasaan, kesimpulannya kutub terpenting dalam demokrasi adalah pada demos-nya. Demos mesti memiliki basis keyakinan, ideologi atau aqidah dalam bahasa agama Islam. Kalau ini yang terjadi, model demokrasi yang berbasis pada kekuatan rakyat yang memiliki akidah yang benar akan banyak menyelamatkan manusia dari kesulitan dunia dan akhirat. Budaya demokrasi bagi umat Islam adalah budaya yang berbasis pada al-Qur'an dan as-Sunnah.

\section{Globalisasi dan Dampaknya Pada Agama}

Sejak kemunculannya pertama kali, istilah globalization menjadi tren untuk diikuti sekaligus memunculkan kekawatiran dari berbagai kalangan. Padahal jika dita'rifkan dengan tepat, kata ini sebenarnya cukup memiliki nilai kemanfaatan. Dalam masyarakat global istilah ini bisa difahami sebagai "pendorong utama sejarah manusia" (a leitmotif of human bistory). Ribuan tahun sebelum akar kata ini "globe" mendunia, kamus Webster menyebutnya "suatu proses yang membuat berbagai kegiatan dan aspirasi menjadi mendunia dalam lingkup dan penerapan" (a proses that renders various activities and aspirations worldwide in scope or applicatuion) digunakan sebagai dalil untuk bermigrasi dari satu kawasan ke kawasan

${ }^{17}$ Acep Aripudin dkk, Da'wah Damaipengantar da' wah antarbudaya, Rosdakarya Bandung, cet. 1 th.2007 hal. 158-159 
yang lain di seluruh dunia. Sejarah perpindahan manusia dalam wacana masa lalu mungkin bisa menjadi semacam 'proto-globalization'.

Secara historis terdapat empat motif pendorong manusia untuk meninggalkan tempat kediaman keluarga dan kampungnya dan mengembara ke tempat lain, yaitu; penaklukan (conquest), keinginan untuk memastikan keamanan dan memperluas kekuasaan politik, kemakmuran (prosperity), upaya mencari kehidupan yang lebih baik, da'wah (proselytizing), menyebarluaskan ajaran tuhan dan mengajak orang lain mengikuti agamanya, dan motif yang lebih duniawi tetapi masih kuat, rasa ingin tahu dan petualangan (curiosity an wonder-lust) ${ }^{18}$. Itulah sebabnya kita bisa lihat dari untaian penulisan sejarah, para tokoh utama 'globalisasi' ini adalah: para pejuang, pedagang, pendakwah dan para petualang.

Karena itu, pemaknaan ulang terhadap globalisasi semakin penting dengan mencermati cara globalisasi itu seharusnya dan bagaimana yang sebenarnya terjadi. Kategori pertama mengindikasikan bahwa globalisasi adalah aspek kehiduapan yang paling riil terkait dengan kecenderungannya sebagai 'zoon politicon' dan ini manusiawi. Kategori kedua, sebagai akibat saling interaksi, seharusnya hubungan dua arah adalah sebuah keharusan, ternyata tidak ! tetap saja yang kuat akan memakai kebebasan dalam ranah globalisasi dan menjadikannya alat untuk menguasai yang lain, dan yang terjadi justru 'begemoni' ${ }^{19}$.

\section{Agama Sistemik.}

Pengertian yang digambarkan di atas, menunjukkan kekuatan globalisasi terhadap perubahan pola dan sikap setiap manusia. Walaupun ia lahir dari hasil karya manusia, ia menjadi kuat karena banyak pengaruh yang saling menyokong dan akhirnya menjadi kekuatan. Dengan demikian jangankan menggantinya dengan kekuatan baru, untuk mengimbanginya saja rasanya harus bersusah payah terlebih dahulu, itupun akan sangat bergantung pada siapa pembawa risalah tersebut. Kekuatan baru itu mesti dilahirkan ( baca: diciptakan) berdasar sifat fitrah manusia dan ajaran itu mestilah sistemik dari sisi kandungan nilai.

Rasulullah saw, sebelum diangkat menjadi rasul, bertahun-tahun terlibat dalam pemikiran dan 'uqlah yang intensif dalam membaca masyarakat komersil dan glamour kota Mekkah. Hasil dari pengamatan dan kontemplasi tersebut, setidaknya muncul tiga fenomena sosio religius

\footnotetext{
${ }^{18}$ Prof. Nur Ahmad Fadhli lubis, Dampak Globalisasi dan Tantangannya terhadap Pendidikan Agama, dalam Ziaudin Sardar, Islam Tanpa Syariat: Menggali universalitas tradisi, Grafindo, hal.178-179

${ }^{19}$ Ibid, hal 182-183 (diringkas)
} 
dari tata sosial yang di bacanya: Pertama, politeisme yang merajalela di mana-mana dan kemudian melahirkan prinsip tauhid. Kedua, kesenjangan sosial ekonomi yang parah antara si kaya dan si miskin. Ketiga, tidak adanya rasa tanggung jawab terhadap nasib manusia secara keseluruhan ${ }^{20}$.

Kelahiran Islam dengan ajaran yang sistemik menjadi jawaban penyingkap kabut kejahiliyahan terutama dalam menemukan konsep ketuhanan. Dan Islam dalam konteks sekarang akan melahirkan kekuatan yang akan menjadi lawan tanding bagi globalisasi, karena sebagaimana pernyataan, Malcom Walters: “. . . . kekuatan ini (globalisasi, pent.) dapat digunakan untuk mengurangi atau babkan menghapus otoritas agama-agama ,.. ... dan sumber kekeuatan lainya". ${ }^{21}$

Dengan demikian sudah dapat dipastikan tinggal agama yang kokoh-lah yang akan bisa bertahan terhadap gempuran globalisasi. Bagaimana dengan agama-agama besar dunia? Kristen telah hancur sejak awal-awal kelahirannya, bagaimana dengan Islam?

Islam sebagai agama sistemik akan menjadi jawaban karena ajaran yang di tawarkan dan asal usul kelahirannya yang jelas bisa dibuktikan. Ajaran dasar yang ditawarkan Islam dari dulu hingga kini tidak pernah berubah semisal yang tercantum dalam Rukun Iman, Islam dan Ihsan. Sebagai sebuah ilustrasi yang dinyatakan oleh Mayor Arthur Glyn Leonard:

"Dua wajah dari pada 'aqidah Islam yang terutama senantiasa menarik, perbatian saya. Pertama, konsepsi tentang Tuban. Kedua, kemurnianny a yang tak terbantah suatu daya yang luar biasa dalam peristiwa kemanusiaan, terutama aspek keAgama-annya. Pendek, kata ketulusannya adalah Ilabi serta yang meliputi sejumlah besar dosa-dosa". ${ }^{22}$

Endang Saifudin menukil dari Sirajini Naidu, menyatakan: "Rasa keadilan adalah citra Islam yang paling mengagumkan, karena sebagaimana yang saya telaah dalam al-Qur'an, saya dapatkan asas-asas bidup yang dinamis, bukan mistik melainkan etika praktis untuk selurub dunia". ${ }^{23}$

\footnotetext{
${ }^{20}$ Ibid, Acep Aripudin, hal. 138

${ }^{21}$ Roubaie, Amer.Prof.Dr, Jurnal Islamia, th. 1 no.4 2005, hal.10-1l

22 Ibid, Endang Saifudin Anshari, hal. 138

${ }^{23}$ Ibid, Endang SA, hal. 139
} 
Dua pernyataan di atas menegaskan pernyataan Qur'an bahwa sifat ke-Tuhanan dalam Islam adalah 'untuk seluruh alam'. Dalam kontek ke dalam, kepada umat Islam sendiri PR terbesar untuk mampu menghadapi gempuran globalisasi adalah merampungkan persoalan-persoalan umat Islam sendiri. Gerakan reformasi dan modernisasi ditawarkan oleh $\mathrm{KH}$. Isa Anshari dengan di tandai oleh :

1) Menemukan kembali ajaran Islam yang murni dan asli, bersumber kepada al-Quran dan as-Sunnah.

2) Umat Islam harus menemukan dirinya sendiri.

3) Menghidupkan rasa percaya kepada diri sendiri.

4) Menghidupkan rub al-jihad, dinamis dan optimis.

5) Sanggup mempertahankan dan membela Islam, menjawab segala tantangan, baik dari dalam maupun dari luar.

6) Mengembangkan kegiatan yang konstruktif untuk memberi isi dan arti kepada revolusi-kerakyatan di segala nation ${ }^{24}$.

\section{KESIMPULAN}

Islam, dengan seluruh perangkatnya, sangat layak menjadi pemain dalam percaturan global. Pesan bahwa agama ini adalah rabmat li al-alamin, adalah satu referensi yang tidak dapat dibantah, agama inipun memang dipersipakan oleh Allah sebagai agama para penduduk bumi, baik sekarang ataupun yang akan datang, baik cocok di tanah kelahiranya, ataupun bagi bangsa-bangsa lain penghuni kolong langit ini. Berangkat dari iman yang kokoh, berbekal dengan keluasan ilmu yang berbasis alQur`an dan As-Sunnah serta menteladani pola hidup dan pola perjuangan generasi awal Islam, kita tebarkan dakwah Islam keseluruh penjuru dunia sebagai rahmat bagi seluruh alam. Hanya kepada Allah kita mengabdi dan hanya kepada-Nya kita memohon pertolongan.

Menghadapi tantangan dakwah di era global yang tergambar sedemikian berat, bagi seorang muslim tersedia beberapa alternatif jawaban. Menurut Bambang Pranowo ada tiga alternatif yakni, (1) Sikap "Isolasi" (2) Sikap "Pasif" (3) Sikap "Selektif", sedangkan dalam hemat penulis dengan mengacu pada langkah dakwah Rasulullah SAW, ada pilihan yang ke (4) yakni sikap "Aktif".

Sikap isolasi yakni menutup diri dari segala pengaruh luar yang mengalir bersama arus globalisasi karena pengaruhnya banyak bersifat negatif. Sikap pasif yaitu sikap yang membiarkan segala proses berlangsung tanpa menghiraukan, baik dampak positif maupun negatif dari proses tersebut. Sedangkan sikap selektif adalah sikap yang senantiasa

${ }^{24}$ Anshari, KH.M.Isa, Mujahid Da’wah, CV.Diponegoro, hal 74 
terbuka terhadap segala perkembangan yang terjadi, kemudian menyaringnya dengan parameter Al-Qur`an dan As-Sunnah, mana yang patut diserap dan mana yang justru harus dibuang.

Sikap aktif itulah yang penulis maksud dengan sikap khoiru ummah, yakni sikap mencermati arus globalisasi dan bahkan memanfaatkan arus globalisasi dengan aktifitas dakwah mengajak kepada yang ma ruf dan mencegah dari yang munkar, namun dirinya sendiri kokoh dalam landasan iman. Itulah jati diri sebagai khoiru ummah sebagaimana dilukiskan sifat-sifat mulia mereka oleh Allah SWT dalam firmanNya:

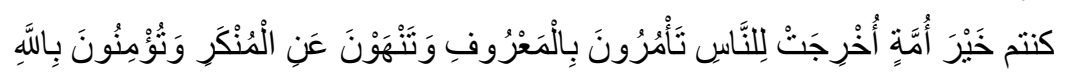

Kamu adalah umat yang terbaik yang dilabirkan untuk. manusia, menyurub kepada yang ma 'ruf, dan mencegab dari yang munkar, dan beriman kepada Allah. ${ }^{25}$

Wallahu a'lam bishawab

\section{DAFTAR PUSTAKA}

A.W. Munawwir, Kamus Al-Munawwir, Edisi kedua

Acep Aripudin dkk, Da'wah Damai pengantar da'wah antarbudaya, Rosdakarya Bandung, cet. 1 th.2007

${ }^{25}$ QS. Ali 'Imran : 110 
Achmad Mubarok, Psikologi Dakwah, ( Jakarta: Pustaka Firdaus 2002 ) Cet. Ke-3

Achmad Mubarok, Psikologi Dakwah, (Jakarta: Pustaka Firdaus, 1999)

Akbar S. Ahmad dan Hastings Donnan, Islam; Globalization and Posmodernity,(London : Routledge, 1994)

Anshari, KH.M.Isa, Mujahid Da'wah, CV.Diponegoro

Asep S. Muhtadi, Dakwah Kontemporer-Pola Alternatif Dakwah Melalui Televisi, (Pusdai Press, 2000)

David C. Korten, When Corporations Rule the World (Bila Korporasi Menguasai Dunia), (Jakarta: Professional Books, 1997)

Endang Saifuddin Anshari, MA, Kuliah Al-Islam, Pent.Pustaka Salman ITB, th 1980, hal. 107

Harlan Cleveland, Lahimya Sebuah Dunia Baru, (Jakarta: Yayasan Obor Indonesia,1995)Cet.Ke-1

J.P. Pronk, Sedunia Perbedaan, (Jakarta: Yayasan Obor Indonesia, 1993),

Jalal Amin dalam Muqaddimah Kitab Al- Ailamah wa At-Tanmiyyah Al-Arabiyyah min Hamlati Nabuliyon Ila Jaulah Urughuway, (Beirut: Markaz Dirasat Al-Wihdah al-'Arabiyah, t.t.)

John Naisbitt \& Patricia Abutrdene, Megatrens 2000 Sepuluh Arah Baru untuk tahun 1990-an, Bina Aksara Jakarta,

Jum`ah Amin Abdul Aziz, Fiqih Dakwah, ( Solo: Era Intermedia 2003 ) Cet. $\mathrm{Ke}-4$

M. Bambang Pranowo, Tantangan Global Pribadi Muslim, (Pokokpokok pikiran disampaikan pada acara Tazkiyah Afidah, diselenggarakan oleh Yayasan Rumah Sakit Islam Jakarta, 24 Mei 2003)

Muhadi Sugiono, Kritik Antonio Gramsci Terhadap Pembangunan Ketiga, (Yogyakarta: Pustaka Pelajar, 1999) Cet. Ke-1

Roubaie, Amer.Prof.Dr, Jurnal Islamia, th. 1 no.4 2005

Sidek Baba, Pendidikan Islam Integratif Benteng Hadapi Globalisasi, (Kuala Lumpur: Minda Madani Online, 11 Mei 2004)

The new Encyclopedia Britanica, vol.3 
Umaimah Wahid, Diktat Mata Kuliah Dakwah dan Media Massa, Pasca Sarjana UIA Jakarta

Yusuf Al-Qardhawi, Islam dan Globalisasi Dunia, (Jakarta: Pustaka AlKautsar, 2001)

Yusuf Al-Qardhawy , Islam dan Globalisasi Dunia, Jakarta: Pustaka Al-Kautsar, 2001)

Ziaudin Sardar, Islam Tanpa Syariat: Menggali universalitas tradisi, Grafindo,

UIA As-Syafi'iyah Program S 2 